\title{
In vitro antibacterial activity of green tea (Camellia sinensis) extract against Staphylococcus aureus and MRSA
}

\author{
Neha Sowjanya S. ${ }^{1}$, Ramya S. R. ${ }^{2, *}$, Reba Kanungo ${ }^{3}$ \\ ${ }^{1}$ 3rd year M.B.B.S Student, ${ }^{2}$ Associate Professor, ${ }^{3}$ Professor \& HOD, ${ }^{2,3}$ Dept. of Microbiology, ${ }^{1-3}$ Pondicherry Institute of \\ Medical Sciences, Kalapet, Puducherry, India
}

*Corresponding Author:

Email: ramyasr121186@gmail.com

\begin{abstract}
Context: There is a worldwide emergence of multi drug resistant bacteria. Recently no new antibiotics have been approved for use, although some are in the pipeline, undergoing phase 2 or 3 clinical trials. There is need for alternate compounds for treatment; one such agent is green tea. Green tea has antimicrobial effects against a variety of Gram positive and Gram negative bacteria (e.g., Staphylococcus aureus, Enterococcus sp, Escherichia coli, Salmonella sp.)

Aims: To determine the antibacterial activity of green tea extract against Methicillin resistant and sensitive Staphylococcus aureus (MRSA \&MSSA)

Settings and Design: Department of Microbiology, Cross sectional study

Materials and Methods: A total of 15 consecutive laboratory isolates of S. aureus (MSSA) and MRSA each, isolated between August to September 2017 were inoculated in media containing Green tea extract [epigallocatechin gallate (EGCG)] in concentrations of $2.5 \mathrm{mg} / \mathrm{ml}, 5 \mathrm{mg} / \mathrm{ml}, 10 \mathrm{mg} / \mathrm{ml}$. After overnight incubation the bacterial broth was subcultured using standard calibrated loop $(0.01 \mathrm{ml})$ onto Mueller Hinton agar. The lowest concentration of EGCG in which no growth occurred was considered as the minimum bactericidal concentration (MBC).

Results: EGCG had antimicrobial activity against $S$. aureus ATCC-25923, P. aeruginosa ATCC-27853, K.pneumoniae ATCCBAA 1705 and Esch.coli ATCC-25922- MBC 99.9\% was 5mg/ml. But for E.faecalis ATCC 29212 MBC 99.9\% was 10mg/ml. EGCG was effective against clinical isolates of MSSA and MRSA with MBC of $5 \mathrm{mg} / \mathrm{ml}$ except 2 MRSA isolates for which $\mathrm{MBC}$ was $10 \mathrm{mg} / \mathrm{ml}$.

Conclusions: Green tea extract- EGCG has antibacterial activity not only against standard bacterial strains but also against clinical isolates of S.aureus and MRSA.
\end{abstract}

Keywords: Camellia sinensis, S.aureus, Minimum bactericidal concentration.

\section{Introduction}

Antimicrobial resistance has been increasing over the years due to overuse of antibiotics. ${ }^{1}$ Hence trivial infections are progressing to become life threatening diseases. S. aureus are highly pathogenic and rate of infection caused by these microorganisms have increased in recent years. With increase in multi drug resistance there is a need for alternate compounds for treatment. One such agent is green tea extract. ${ }^{2}$

Camellia sinensis (green tea) has a wide range of antioxidant, anti inflammatory, anti-carcinogenic and antibacterial activity against many pathogens. ${ }^{2}$ Green tea is used in the treatment of cardiovascular diseases and obesity. It is safe, non toxic and has no side effects. $^{3}$ Green tea has antimicrobial effects against a variety of Gram positive and Gram negative bacteria(e.g., Staphylococcus aureus, Enterococcus sp, Escherichia coli, Salmonella sp), some fungi(e.g., Candida albicans), and a variety of viruses(e.g., HIV, Herpes simplex virus, Influenza virus). ${ }^{4,5}$

The chemical composition of green tea is complex and incompletely defined. The most abundant components in green tea are polyphenols, mostly flavonoids such as catechins, catechingallates and proanthocyanidins. ${ }^{6}$

The biological properties of green tea are due to the catechin fraction, which constitutes up to $30 \%$ of the dry leaf weight. There are four main catechins in tea. Epicatechin (EC), epicatechin-3-gallate (ECG), epigallocatechin (EGC), and epigallocatechin-3- gallate (EGCG). EGCG is the most abundant, representing approximately $59 \%$ of the total catechins. ${ }^{7}$

The EGCG-induces damage to the bacterial cell wall with possible interference of its biosynthesis through direct binding with peptidoglycan. This may be one of the major reasons for its antimicrobial activity against Methicillin sensitive and resistant $S$. aureus (MSSA \&MRSA). ${ }^{8}$

The present study was designed to assess the in vitro antibacterial activity of green tea extract against MSSA and MRSA isolated from clinical specimens with an objective to design possible therapeutic approach to infections caused by them, by determining Minimum Bactericidal Concentration (MBC) of epigallocatechin gallate (EGCG), extracted from green tea.

\section{Materials and Methods}

The present study (IEC-RC/17/02) was reviewed by the Institute Ethics committee and a waiver of consent was obtained as it did not involve human participants. The cross sectional study was conducted in the Department of Microbiology, Pondicherry Institute 
of Medical Sciences, Puducherry between August to September 2017. During this period 15 consecutive isolates each of MSSA and MRSA were included.

All $S$. aureus were identified as per standard microbiological protocols. ${ }^{9}$ MRSA was identified based on resistance to antibiotic disc Cefoxitin $(30 \mu \mathrm{g})$ with inhibition zone diameter $<22 \mathrm{~mm}$ by Standard Disc diffusion method as per CLSI guidelines. ${ }^{10} \mathrm{~A}$ second screening test for MRSA was performed with $6 \mathrm{mg}$ of oxacillin per $\mathrm{ml}$ on Mueller Hinton (MH) agar supplemented with $4 \% \mathrm{NaCl}^{10}$

Commercially available green tea extract with active ingredient being (-)-epigallocatechin gallate (EGCG) manufactured by Sigma Aldrich (Lot No SLBP0484V) was used in this study. Minimum Bactericidal Concentration (MBC) of Green Tea extract against MSSA and MRSA was done by Broth Dilution method. Different concentrations of EGCG $(2.5 \mathrm{mg} / \mathrm{ml}$, $5 \mathrm{mg} / \mathrm{ml}, 10 \mathrm{mg} / \mathrm{ml}$ ) was prepared using Mueller hinton broth. These concentrations were based on the pilot study. S. aureus was inoculated into peptone water and the turbidity was matched to $0.5 \mathrm{Mc}$ Farland standard (Himedia, India) corresponding to bacterial density of $1.5 \times 10^{8} \mathrm{cfu} / \mathrm{ml}$. $100 \mu \mathrm{l}$ of bacterial broth and $100 \mu \mathrm{l}$ of EGCG (different concentrations were tested) in microtitre wells was incubated at $37^{\circ} \mathrm{C}$ overnight(Fig 1). The bacterial broth was subcultured using standard calibrated loop $(0.01 \mathrm{ml})$ onto Mueller Hinton agar. The lowest concentration of EGCG in which no growth occurred was defined as the MBC. Appropriate controls of uninoculated Mueller Hinton broth without any supplements, uninoculated Mueller Hinton broth(MHB) containing Green tea extract at a concentration of $2.5 \mathrm{mg} / \mathrm{ml}, 5 \mathrm{mg} / \mathrm{ml}$ and $10 \mathrm{mg} / \mathrm{ml}$ as EGCG control and $200 \mu 1$ of bacterial isolate in MHB without Green tea extract were used.

Staphylococcus aureus ATCC 25923, Esherichia coli ATCC 25922, Enterococcus faecalis ATCC 29212, Pseudomomas aeruginosa ATCC 27853, Klebsiella pneumoniae ATCC BAA 1705 were also tested for assessing efficacy of EGCG.

\section{Results and Discussion}

The results of the study showed that the green tea extract epigallocatechin gallate (EGCG) exhibited a potent antibacterial activity as detected by minimum bactericidal activity. The antimicrobial activity of commercial EGCG against Standard bacterial strains and Clinical isolates of MSSA and MRSA is depicted in Tables 1 and 2 respectively.

Control strains, MSSA and MRSA showed growth in the absence of EGCG.

Amongst the standard bacterial strains EGCG had highest antimicrobial activity with $99.9 \% \mathrm{MBC}$ at a concentration of $5 \mathrm{mg} / \mathrm{ml}$ against $S$. aureus ATCC25923, P. aeruginosa ATCC-27853, K.pneumoniae ATCC-BAA 1705 and Esch.coli ATCC-25922. Against E.faecalis ATCC 29212, 99.9\% MBC was $10 \mathrm{mg} / \mathrm{ml}$ concentration (Fig. $2 \& 3$ ).

Amongst the 15 isolates of MRSA, EGCG exhibited antimicrobial activity. MBC was $5 \mathrm{mg} / \mathrm{ml}$ except two isolates 5 and 10.For isolate number 5 and $10 \mathrm{MBC}$ was $10 \mathrm{mg} / \mathrm{ml}$ (Fig. $3 \& 4$ ). Amongst the 15 isolates of MSSA, MBC was $5 \mathrm{mg} / \mathrm{ml}$ (Fig. 3). At $2.5 \mathrm{mg} / \mathrm{ml}$ of EGCG all standard bacterial strains, MSSA and MRSA there was growth (Fig. 4).

The active ingredient of Green tea, Camellia sinensis has been reported to have antibacterial activity against various pathogenic bacteria including MRSA. ${ }^{11}$ The present study showed that commercially available Epigallocatechin gallate (EGCG) from green tea extract has antimicrobial activity not only against standard ATCC strains but also against clinical isolates of MSSA and MRSA. Our observations are in accordance with other studies which have shown that green tea extract exhibit antimicrobial activity against highly resistant bacterial strains such as MRSA. ${ }^{11-16}$

Green tea catechins interfere with bacterial DNA replication by inhibiting the function of DNA gyrase. The polyphenols of green tea can inhibit the enzyme dihydrofolate reductase in bacteria and yeast effectively blocking the ability of microbes to synthesize purines and pyramidine. ${ }^{7}$ Studies have suggested that main polyphenolic component of green tea is Epigallocatechin gallate which can lead to reversal of methicillin resistance in MRSA by inhibiting synthesis of PBP2. 7,12,17

Further studies need to be carried out to determine the optimal concentration of green tea extract required for its inhibitory activity. Moreover, it needs to be determined whether these concentrations can be achieved and sustained in vivo. The EGCG plasma concentration after intake of Green tea needs to be evaluated.

Table 1: MBC of EGCG against Standard bacterial strains

\begin{tabular}{|l|c|}
\hline \multicolumn{1}{|c|}{ ATCC strains } & MBC \\
\hline Staphylococcus aureus ATCC 25923 & $5 \mathrm{mg} / \mathrm{ml}$ \\
\hline Escherichia coli ATCC 25922 & $5 \mathrm{mg} / \mathrm{ml}$ \\
\hline Pseudomonas aeruginosa ATCC 27853 & $5 \mathrm{mg} / \mathrm{ml}$ \\
\hline Enterococcus faecalis ATCC 29212 & $10 \mathrm{mg} / \mathrm{ml}$ \\
\hline Klebsiella pneumoniae ATCC BAA 1705 & $5 \mathrm{mg} / \mathrm{ml}$ \\
\hline
\end{tabular}


Table 2: MBC of EGCG against Staphylococcus aureus and MRSA isolates

\begin{tabular}{|c|c|c|c|}
\hline $\begin{array}{c}\text { MRSA Isolate } \\
\text { Number }\end{array}$ & MBC & $\begin{array}{c}\text { MSSA Isolate } \\
\text { Number }\end{array}$ & MBC \\
\hline 1 & $5 \mathrm{mg} / \mathrm{ml}$ & 16 & $5 \mathrm{mg} / \mathrm{ml}$ \\
\hline 2 & $5 \mathrm{mg} / \mathrm{ml}$ & 17 & $5 \mathrm{mg} / \mathrm{ml}$ \\
\hline 3 & $5 \mathrm{mg} / \mathrm{ml}$ & 18 & $5 \mathrm{mg} / \mathrm{ml}$ \\
\hline 4 & $5 \mathrm{mg} / \mathrm{ml}$ & 19 & $5 \mathrm{mg} / \mathrm{ml}$ \\
\hline 5 & $10 \mathrm{mg} / \mathrm{ml}$ & 20 & $5 \mathrm{mg} / \mathrm{ml}$ \\
\hline 6 & $5 \mathrm{mg} / \mathrm{ml}$ & 21 & $5 \mathrm{mg} / \mathrm{ml}$ \\
\hline 7 & $5 \mathrm{mg} / \mathrm{ml}$ & 22 & $5 \mathrm{mg} / \mathrm{ml}$ \\
\hline 8 & $5 \mathrm{mg} / \mathrm{ml}$ & 23 & $5 \mathrm{mg} / \mathrm{ml}$ \\
\hline 9 & $5 \mathrm{mg} / \mathrm{ml}$ & 24 & $5 \mathrm{mg} / \mathrm{ml}$ \\
\hline 10 & $10 \mathrm{mg} / \mathrm{ml}$ & 25 & $5 \mathrm{mg} / \mathrm{ml}$ \\
\hline 11 & $5 \mathrm{mg} / \mathrm{ml}$ & 26 & $5 \mathrm{mg} / \mathrm{ml}$ \\
\hline 12 & $5 \mathrm{mg} / \mathrm{ml}$ & 27 & $5 \mathrm{mg} / \mathrm{ml}$ \\
\hline 13 & $5 \mathrm{mg} / \mathrm{ml}$ & 28 & $5 \mathrm{mg} / \mathrm{ml}$ \\
\hline 14 & $5 \mathrm{mg} / \mathrm{ml}$ & 29 & $5 \mathrm{mg} / \mathrm{ml}$ \\
\hline 15 & $5 \mathrm{mg} / \mathrm{ml}$ & 30 & $5 \mathrm{mg} / \mathrm{ml}$ \\
\hline
\end{tabular}

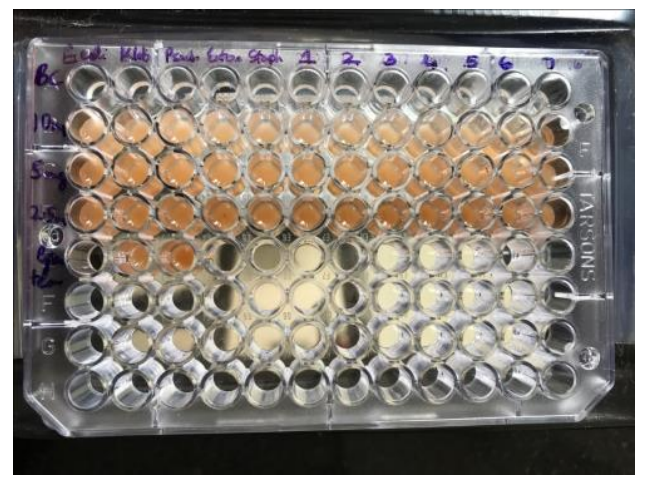

Fig. 1: Microtitre wells with EGCG and Bacterial broth

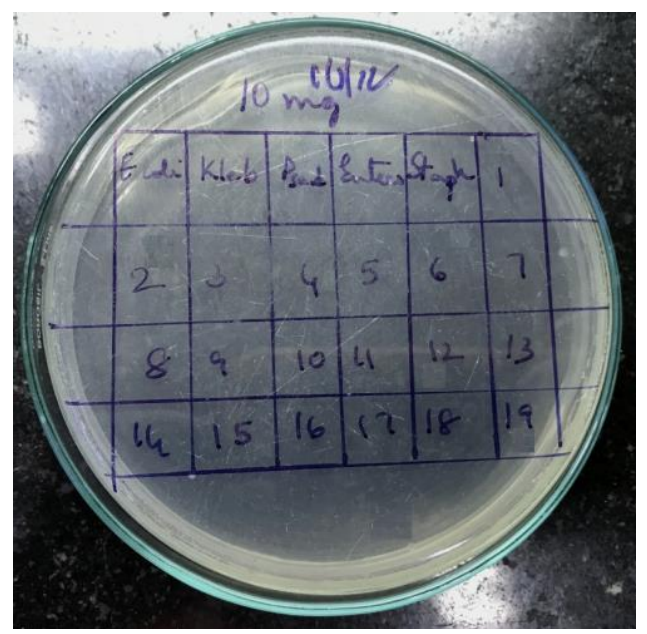

Fig. 2: EGCG of $10 \mathrm{mg} / \mathrm{ml}$ with bacterial broth of ATCC strains, S.aureus and MRSA isolates subcultured onto MHA

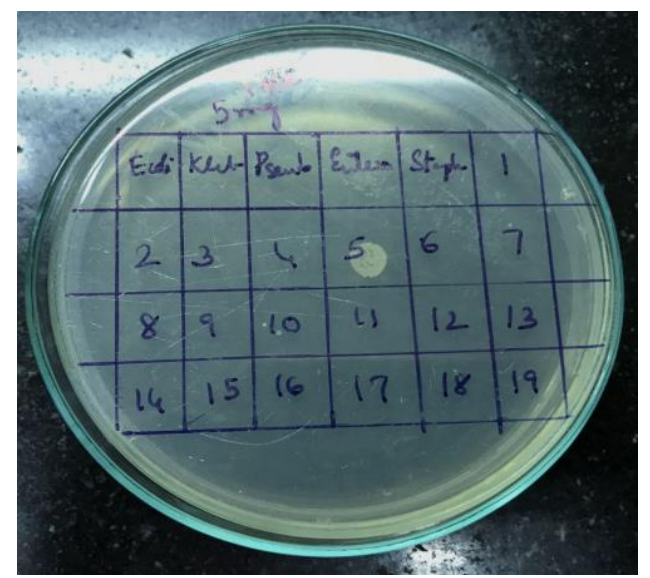

Fig. 3: EGCG of $5 \mathrm{mg} / \mathrm{ml}$ with bacterial broth of ATCC strains, S.aureus and MRSA isolates subcultured onto MHA

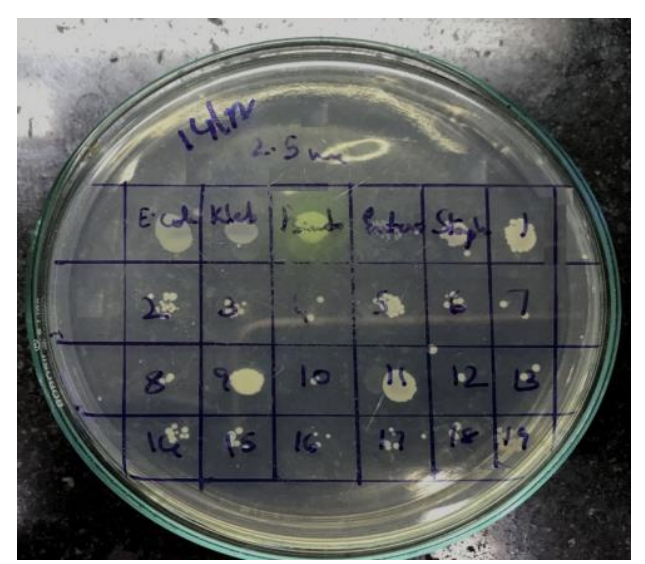

Fig. 4: EGCG of $2.5 \mathrm{mg} / \mathrm{ml}$ with bacterial broth of ATCC strains, S.aureus and MRSA isolates subcultured onto MHA 


\section{Limitations}

Only few clinical isolates were tested in the present study. The antibacterial activity of green tea extract EGCG against multi drug resistant bacteria like MDR Acinetobacter, Pseudomonas and other nosocomial pathogens were not evaluated.

\section{Conclusion}

Green tea (Camellia sinensis) extract EGCG which is commercially available acts as a potent antibacterial agent. It is effective against against $S$. aureus ATCC25923, P. aeruginosa ATCC-27853, K.pneumoniae ATCC-BAA 1705 and Esch.coli ATCC-25922, E.faecalis ATCC 29212 and against clinical isolates of S.aureus and MRSA. These green tea extract (polyphenolic compounds) can be used as singly or as adjuvant therapeutic agent in the treatment of multidrug resistant infections.

Funding: PIMS student fellowship.

Conflict of interest: None declared.

\section{References}

1. Ventola CL. The antibiotic resistance crisis part 1 causes and threats. P T. 2015;40(4): 277-83.

2. Tiwari TP, Bharti SK, Kaur HD, Dikshit RP, Hoondal GS. Synergistic antimicrobial activity of tea \& antibiotics. Indian J Med Res 2005;122(1):80-4.

3. Diane L. McKay and Jeffrey Blumberg B. Roles for EpigallocatechinGallate in Cardiovascular Disease and Obesity: An Introduction. J Am College Nutrition 2007;26(4):362S-365S.

4. Steinmann, J., Buer, J., Pietschmann, T., and Steinmann, E. Anti-infective properties of epigallocatechin-3-gallate (ECGC), a component of green tea. Br J Pharmacol 2013;168:1059-73.

5. Jigisha, A., Nishant, R., Navin, K., and Pankaj, G. Green tea: a magical herb with miraculous outcomes. Int Res $J$ Pharm 2012;3:139-48.

6. Graham H. Green tea composition, consumption and polyphenol chemistry. Preventive Med 1992;21:334-50.

7. Reygaert WC. The antimicrobial possibilities of green tea. Front Microbial 2014;5:1-8.

8. Zhao WH, Hu ZQ, Okubo S, Hara Y, Shimamura T. Mechanism of synergy between epigallocatechin gallate and -lactams against methicillin-resistant Staphylococcus aureus. Antimicrob Agents Chemother 2001;45(6):173742.

9. Tille, Patricia M. Bailey \& Scott's Diagnostic Microbiology. 13th edition. St. Louis, Missouri: Elsevier; 2014.

10. Clinical Laboratory Standards Institute. Performance Standards for Antimicrobial Susceptibility Testing; Twenty-Fifth Informational Supplement ed. CLSI document M100-S25. CLSI: Wayne, PA; 2015.

11. Dubey N, Mehta A. In vitro study of the antimicrobial property of Green tea extract against standard (ATCC) bacterial strains and clinical isolates of Methicillin Resistant Staphylococcus aureus \& Multidrug Resistant Pseudomonas aeruginosa. Indian J Microbiol Res 2016;3(3):230-35.

12. Radji M ,Agustama RA, Elya B, Tjampakasari CR. Antimicrobial Activity of Green Tea Extract Against Isolates of Methicillin Resistant Staphylococcus aureus and Multi drug Resistant Pseudomonas aeruginosa. Asian Pac J Trop Biomed 2013;3(8):663-67.

13. Fanaki NH, Kassem MA, Fawzi MA, Dabbous SE. Influence of Aqueous Green Tea Extract on the Antimicrobial Activity of Some Antibiotics Against Multiresistant Clinical Isolates. Egyptian J Med Microbiol 2008;17(3):449-60.

14. Cho YS, Schiller NL, Heon oh K Antibacterial effects of Green Tea polyphenols on clinical isolates of Methicillin Resistant Staphylococcus aureus. Curr Microbiol 2008;57:542-46.

15. Koech VR, Wachira FN Ngure RM, Wanyoko JK, Bilc and Karori SM. Antimicrobial and Synergistic activity of different tea crude extracts against antibiotic resistant $S$. aureus, E.coli and a Clinical Isolate of S. typhi. Sci J Microbial 2013;115:1-9.

16. Jazani NH, Shahabi Sh, Ali AA, Zartoshti M. Antibacterial effects of Water Soluble Green Tea extracts on Multiantibiotic resistant isolates of Acinetobacter sp. Pak J Biol Sci 2007;10:1477-80.

17. Yam TS, Hamilton-miller JMT, Shah S. The effect of a component of tea (Camellia sinensis) on methicillin resistance, PBP2 Synthesis and $\beta$-lactamase production Staphylococcus aureus. J Antimicrob Chemother 1998;42:211-16.

How to cite this article: S. Neha, Ramya R., Kanungo R. In vitro antibacterial activity of green tea (Camellia sinensis) extract against Staphylococcus aureus and MRSA. Int J Med Microbiol Trop Dis 2018;4(4):214-17. 